\title{
Postmodernity's Unexpected Arrival: 1968 as Breakdown in Geoculture
}

\author{
Georgi M. Derluguian
}

Two things appear striking about 1968: how profound was the historical break, and how little about it remains appreciated. Let us begin with such a visible indicator of epochal change as dress fashions. The historian Eric Hobsbawm observed: "fashion-designers, a notoriously non-analytic breed, sometimes succeed in anticipating the shape of things to come better than professional predictors." "The 1960s ushered in a true "Gap" in the evolution of fashions that is still with us. The blue jeans and t-shirts of erstwhile farmers, now on the youths of both sexes, amounted to a revolution in status consumption. For the first time in history, we hope to maintain "immature" adolescent looks and behaviors.

These are impressionistic observations. What caused this epochal change? Why does the present look so contradictory? If the meaning of 1968 was social revolution, why are inequalities in so many countries back to the levels of early capitalism, if not feudalism? Resistances, critiques, and rebellions remain near ubiquitous. In a real sense, the revolution of 1968 has never ended. I am writing these lines in Armenia when student protestors, having toppled the country's erstwhile president, now occupy the university demanding full financial audit. The older Armenians, however, remain skeptical: they have seen it all before.

But what dashed the hopes of 1968 and 1989? Why did the grand projects of High Modernity collapse at these symbolic dates? Our epoch seems more confused rather than revolutionary. The loudest critiques are from the far right. The new populists of all countries borrow from 1968 the tactics of socialmovement mobilization. The confusion blossoms in the labels proposed for the post-1968 period. The prefixes post- and neo- suggest that the present does not qualify for its own name. It is rather post-industrial, post-Fordist, post-colonial, post-Soviet, neo-liberal, et cetera.

Postmodernity seems a usefully broad definition if we accept it simply as what arrives after the breakdown of modernity's grand projects. The former USSR offers rich empirical sites for investigating postmodernity, surely because the Soviet project was the epitome of what James Scott has analyzed as High Modernism with its brutally straightforward plans for achieving superior efficiency and the ultimately inhuman results leading to moral failure. ${ }^{2}$ Let me unpack this grand statement by relying on micro-level examples from my own sociological research in the Caucasus. After all, no global trend can have meaning unless observed in specific situations.

1. Eric Hobsbawm, The Age of Extremes: A History of the World, 1914-1991 (New York, 1991), 178.

2. James C. Scott, Seeing Like a State: How Certain Schemes to Improve the Human Condition Have Failed (New Haven, 1998). 
Nearly two decades ago, my first monograph was intended as an eyewitness commentary on the Soviet collapse. ${ }^{3}$ It has since moved into a realm of history that does not make intuitive sense to younger readers. The book used three analytical lenses: the general evolution of the capitalist world-system, the dilemmas of an anti-systemic project to build a large socialist state, and its sudden breakdown seen from the ethnic periphery in the Caucasus. The leitmotif unifying the narrative was found in the life trajectory of a certain Yuri Muhamedovich Shanibov, or Musa Shanib in his perestroika-era capacity of Circassian nationalist leader, himself a 68er.

Shanibov's colorful personality embodied many paradoxes. In 1989-93, he was often called the Garibaldi of the Caucasus. Shanibov headed rebellious crowds and eventually the armed volunteer battalions. In appearance, the clean-shaven Shanibov, dressed in an ordinary business suit, might seem the provincial Soviet official that he once was, if not for the resplendent silverycurly sheepskin hat and traditional Circassian papakha, proudly worn even indoors in display of ethnic identity. The biggest surprise was Shanibov's proving conversant in the political sociology of Pierre Bourdieu. The fascinated Bourdieu himself demanded to know more about his distant reader in papakha.

Born in 1936, Shanibov belonged to the generation of Soviets orphaned by Stalin's repression and war, which was also the generation that reaped the greatest benefits of Soviet modernization. In his early twenties, the ascendant "national cadre" became a Komsomol apparatchik and district attorney. His career, however, had stalled because Shanibov's enthusiasm for socialist reforms after 1968 looked suspect. Transferred to a local university, Shanibov would spend the era of Brezhnev's "stagnation" without promotions. Still, his interests remained typically broad: Hegel and Freud, cybernetics and cinema, the search for paleo-hominids (the Snow Man, this being the Caucasus), but also Czechoslovak market socialism and Yugoslav self-governance. In Yuri Shanibov we meet a life-long social reformer of the 1960s formation, shestidesyatnik and soixant-huitard in French, a '68er. Why then in 1989 did he embrace ethnic militancy rather than liberal democracy like other 68ers, such as Vaclav Havel or Andrei Sakharov?

One of Shanibov's colleagues pointed me to the answer: "Our Yura for his whole life pursued really the same ideals of democratic self-governance; only the referent groups of his projects had been shifting from students and socialist workers to indigenous nationalities."4 The explanation of Shanibov's personal political transformation thus also had to be structural and macrohistorical. His life fully reflected the changing epochs of eastern Europe.

Yuri Muhamedovich (his birth name of Musa stayed in the family) readily admitted that in his adolescence he was a devote Stalinist. For him, Stalin embodied the enormous transition to modern life in a great, victorious country. Shanibov grew disillusioned with Stalin in the early 1960s when, as district attorney (prokuror), he found a file on his father's denunciation by a

3. Georgi Derluguian, Bourdieu's Secret Admirer in the Caucasus: A World-System Biography (Chicago, 2005).

4. Docent Zh-v, personal interview, Nalchik, Russia, July 07, 2002. 
neighbor in the police archives. This personal experience was in line with the contemporary reflections of younger Soviet nomenklatura on memories of terror. Commonly, they sought to preserve loyalty to their own political system in the comforting calls to revive the Leninist norms of socialist legality. From the murderous charismatic cult of Stalin, the Soviet state was moving into a predictable bureaucratization that was fraught, however, with the pathologies of tolerated inefficiencies, nepotism, and corruption.

The dissipation of Soviet power was materially comfortable. Yet, Soviet conservatives and progressives alike experienced it as deeply troubling. The command economy must have commanders, but the overcautious elders now in charge of the USSR hardly looked commanding. The problem was crisply diagnosed at the time by the dissident Andrei Amal'rik, a spontaneous sociologist and quintessential '68er. In his once-famous underground pamphlet, Amal'rik wrote that Soviet officialdom, having suppressed all discussion after 1968, denied itself alternative policy formulations. ${ }^{5}$ Later, the American political scientist Valerie Bunce gave the dilemma a pithy formulation: "Major reform was as necessary as it was politically impossible." 6

What social forces stalled the reforms? What doomed to rustication the enthusiastic reformer Yuri Shanibov? Why did he finally burst into frenetic action after perestroika, this time as an ethnic warlord? It appears that all the answers are in the aftermath of 1968.

Peters Evans, a prominent sociologist of Third World development, was concerned with non-socialist states like Brazil and South Korea. Yet his theory applies to the Soviet experience. Evans observed that the so-called "developmental states" in time accumulate three kinds of class pressures towards self-dismantlement. ${ }^{7}$ First, the managerial elites themselves secretly desire liberation from dictatorial controls and inhuman workloads. They want to enjoy the fruits of power and pass them to their children because that is what elite families are for. Controlled liberalization and the privatization of industrial assets is the prime choice of such elites on the road to class power. Note that this referred to Hyundai rather than Gazprom or AutoVAZ.

Secondly, industrial labor starts pushing for better wages and conditions once the influx of cheap rural and women's labor has been exhausted. ${ }^{8}$ On its own, the proletarian agenda stays limited to trade-unionist bargaining. In the Soviet bloc, ironically, the inherited leftist ideology left no space for independent unions. With collective bargaining excluded, subterfuge became the prevalent proletarian strategy. The shoddy quality of Soviet products (excepting the military-industrial complex) in fact meant a perverted victory of workers in the face of a decaying bureaucracy fearful of consequences. The east European proverb "they pretend to pay, and we pretend to work" corresponds

5. Andrei Amal'rik, Will the Soviet Union Survive until 1984? (New York, 1981).

6. Valerie Bunce, Subversive Institutions: The Design and Destruction of Socialism and the State (Cambridge, Eng., 1998), 37.

7. Peter B. Evans, Embedded Autonomy: States and Industrial Transformation (Princeton, 1995).

8. Beverly J. Silver, Forces of Labor: Workers' Movements and Globalization since 1870 (New York, 2003). 
to what was once denounced by the philosopher Herbert Marcuse in the west as "repressive tolerance." "

The third source of pressure for dismantling the despotic developmental state emerges from the new middle classes of creative specialists whose numbers and significance multiply with industrialization. Once the bureaucratic oligarchy reigned in political repression, the mid-ranking cadres could openly demand professional autonomy and status. The logical next demand is for a political voice in formulating state policies and electing officials. This means democratization. Its carrier class, once it becomes a Marxist class-for-itself, was famously called the intelligentsia in eastern Europe. Still, to succeed, the intelligentsia must make alliance with the lower strata, or the "people."

The idea of the people as state sovereign, having first become a reality with the American Revolution of 1776 and the French Revolution of 1789, ended the long premodern age characterized by the extreme inequalities of agrarian societies. ${ }^{10}$ The 1848 wave of revolutions completed the transition to modern politics. Two rival political programs for mobilizing the people had crystallized in the wake of 1848: socialism and nationalism. ${ }^{11}$ They appeared as rivals precisely because they were competing for the same popular constituencies. The Bolsheviks, as good Marxists, opposed nationalism before 1917. Yet during the civil war, Lenin decided to lead the non-Russian nationalities rather than leaving them to the "bourgeois" nationalists. The Bolsheviks succeeded as national developmentalists precisely because they were themselves modernistic internationalists committed to the bright future of electricity. In the apt words of American political scientist Stephen Hanson, the Leninists invented the power hybrid that Max Weber himself could not have imagined: a charismatic-rational bureaucracy. ${ }^{12}$

Fifty years later, by 1968, the USSR had become a mature military-industrial superpower ruled by bureaucracy minus revolutionary charisma. Yet the capitalist west, contrary to prophecies, also prospered under the novel set of regulations variously called Fordist or Keynesian. At such unprecedented levels of prosperity and internal pacification, who wanted to risk atomic war?

Modernity, forgive the unavoidable technological determinism, in the main consisted of the ramifying consequences of gunpowder revolution in the arsenal of social power. The key concerns of modern states were in extracting taxes and recruits for the ever-growing military forces, fostering industries to supply the armies and navies, and national citizenship to inspire and unite it all.

Postmodernity then comes among the results of atomic weapons that rendered great-power warfare suicidal. Convergence emerges instead as the elites' catchword in the early 1960s. Western technocrats hoped to meet their

9. Barrington Moore Jr., Herbert Marcuse, and Robert Paul Wolff, A Critique of Pure Tolerance (Boston, 1965).

10. Michael Mann, The Sources of Social Power, vol. 2, The Rise of Classes and NationStates, 1760-1914 (Cambridge, Eng., 1986).

11. Immanuel Wallerstein, The Modern World-System, vol. 2, Centrist Liberalism Triumphant, 1789-1914 (Berkeley, 2011).

12. Stephen Hanson, Time and Revolution: Marxism and the Design of Soviet Institutions (Chapel Hill, 1997). 
communist rivals, who were now visibly interested in consumerism and market experiments, halfway.

In the USSR, the prospect of the so-called konvergentsia captivated the enlightened nomenklatura, including the young Yuri Shanibov and his neighbor from Stavropol', Mikhail Gorbachev. An honorable ideological compromise to secure peace and prosperity no less appealed to intelligentsias in both east and west. The establishment-defying revolts of 1968, however, soon struck on both sides, pointing to a certain reality in convergence. ${ }^{13}$

In biology, the term convergence describes distinct species evolving analogous adaptations to similar environments, like fast-swimming sharks and dolphins. The loudly pronounced differences between the USA and the USSR disguised their many acquired similarities. Both superpowers credited themselves with defeating fascism and bringing about peace, both willfully turned their backs on the dreadful pre-war decade, and both boasted prosperity and optimism. Moscow and Washington attributed this success to their visionary leadership, informed by modern science. In fact, both superpowers built enormous war-planning bureaucracies that were repurposed rather than dismantled in the new era of peace. Big States achieved unprecedented industrial growth and fostered the educated middle classes. For the USA and USSR, it remained to seek self-validation in sharing their versions of modernity with the rest of humanity.

The United States was the first to stumble into quagmire while defending its client modernizers in Vietnam. A decade later, the Soviets did the same in Afghanistan. A peripheral yet centrally experienced war wrought escalating material and moral costs. Both superpowers hastened to repair the damage by accelerating their investments in international aid, defense budgets, and domestic consumption. The simultaneous provision for guns and butter strained the budgets further while wars no longer justified economic hardship. Washington was also the first to pledge domestic reforms and international détente-under a figure as unlikely as Richard Nixon. In time, Moscow responded with the improbable romantic Mikhail Gorbachev.

The crisis reforms produced revolutionary situations as the ruling elites factionalized in two dimensions: hardliners versus accommodationists and centralists versus the localists. The splits invited the intelligentsia's entrance into politics on all sides. The debates grew louder in the absence of easy solutions and authoritative powers. The generalized sense of impasse provoked still more activist movements seeking broader support among classes ordinarily not involved in politics.

Two kinds of competing programs emerged. One promised universalistic social redistribution through the democratic takeover of the state apparatus. More socialism, in short. But state finances were already overstrained, while influential segments in the establishment were stiffening their defenses. In a fundamental sense, the revolts of 1968 and 1989 tested the limits of economic redistribution in the existing system.

The other kind of insurgent politics mobilized particular status groups, nowadays called identities. In effect, this is the program of splitting the state

13. Jeremi Suri, The Global Revolutions of 1968 (New York, 2007). 
along the lines of race, gender, or nationality. It would best suit those peripheral actors who, like our Shanibov, could not project influence in the central political arena. It would suit even better, however, those opportunistic members of state elites who desperately fortify their immediate positions and even profit from collapse.

Revolutionary situations do not always bring revolutionary outcomes. Revolutions may end in state collapse, foreign intervention, or lasting political fragmentation. ${ }^{14}$ This is what actually happened in the Soviet Union after 1989. The two superpowers had been converging in the general design of state machinery, but where the powerful American Cadillac veered into conservative restoration, the Soviet semi-military UAZ skidded to debacle.

Metaphors aside, the Soviet Union was taken apart by its own elites during the 1989 moment of panic. Its dress rehearsal, in Lenin's celebrated expression, was 1968 and everything that followed in Soviet bloc. This indicates where we might find explanations for the bizarre behaviors of all actors in 1989. The arch-typical biography of Shanibov illuminated in detail how his opponents in the communist establishment simply fled sidewise instead of deploying their formidable means of repression. An active resistance in the face of politically-mobilized people appeared futile. The delayed effects of the 1968 "dress rehearsal" extended even in the Caucasus. This is why the events looked so sudden and at the same time so preordained.

Shanibov's political biography helps us appreciate why the rebel intelligentsia embraced market radicalism or, alternatively, ethnic conflicts, so readily abandoning their erstwhile dreams of socialism with a human face. It also resulted from the dynamic of ideological polarization that is seen in all revolutions, especially those that take years to unfold, like the Russian revolutionary sequence from 1905 to 1917 and the Soviet bloc sequence from 1968 to 1989. Everyone in the end knew their part in the script, but nobody could really see what was going to happen next. It was beyond everyone's believing. Who knew that the fragments of a superpower, instead of catching up with the wealthy west, would recoiling to the world-system's periphery?

The 1968 anarchistic explosion in world geoculture irreversibly discredited the bureaucratic modernism of the Big State. In the absence of positive alternative, however, what could become the central reality of postmodernity if not neoliberal capitalism on a global scale? Globalization and neoliberalism, themselves western capitalist reactions to the crisis of 1968, would structure the new post-Soviet realities, with great profits for some and ruin for a great many.

In the former USSR, the ironies of postmodernity proved grotesque. The nimbler elements of the ex-communist elites found salvation in hijacking the three originally anti-bureaucratic demands: national sovereignty, competitive elections, and privatization. After 1989, post-Soviet elites recombined in a series of messy transitions to grab the spoils and fortify their new oligarchic positions or, this failing, ferret the loot to Cyprus. The successor states

14. Arthur L. Stinchcombe, "Ending Revolutions and Building New Governments," Annual Review of Political Science, vol. 2 (June 1999): 49-73. 
became the familiar vehicles of private accumulation and protection accessible only to corrupt insiders.

Once the commitments of the Soviet state to modernization were shed, the intelligentsia also lost its prestige, purpose, and material conditions-and became the target for jokes. The new markets proved too narrow and monopolistic to allow for independent professional incomes, let alone positions of public relevance.

Could it have turned out differently? Back in 1968, the American sociologist Immanuel Wallerstein predicted that reformers in Moscow could have but one positive destination: a reintegration of the Soviet Union into capitalist Europe on honorable terms. ${ }^{15}$ Mikhail Gorbachev's ideological naiveté aside, this was a difficult proposition due to the complexity of the Soviet state and its geopolitically-demanding status as rival to America. Yet the historical possibility seems real enough. Communist China rejoined capitalism without any collapse. Of course, in 1989 China was not a superpower, but then the exclusive position of superpower and its vast scientific-industrial assets had once appeared as the strongest Soviet advantages in bargaining for a good place next to Germany, France, and other post-imperial democracies on the European continent. In this event, a capitalist globalization would still organize the world today. It would look different, however, from what we have actually experienced since the collapse of Soviet Union and the triumph of Washington consensus. The same Immanuel Wallerstein despairing at the course of events in 1991 made another prediction: "East European reformers will reach the promised shores of America. But it will be South, not North America. ${ }^{16 ”}$

What remains from 1968? A lot in what surrounds us, starting with fashions as an indicator of epochal change. Almost all of our intellectual and political trends go back to 1968, the pinnacle and breaking point of modernity. It marked the end of the "Old Left," comprised of Social-Democratic and New Deal reformism in the west, communist parties in eastern Europe, and anticolonial rebels in the Third World. 1968 saw the efflorescence of various New Left currents whose values and goals stay with us, if we care to notice.

Globalization and neoliberalism are also very much consequences of 1968: they were the unregulated transnational space that served as the great escape for western capitalists when political demands for more redistribution looked too threatening in the confines of nation states. After 1989, the new political capitalists emerging from the former communist states would join the global escape from national confines, sealing the triumph of neoliberalism, at least for a while.

15. These hypotheses are revisited in Georgi Derluguian, "What Communism Was," in Immanuel Wallerstein, Randall Collins, Michael Mann, Georgi Derluguian, and Craig Calhoun, Does Capitalism Have a Future? (Oxford, 2013), 99-130.

16. Giovanni Arrighi, Terence K. Hopkins, and Immanuel Wallerstein, "1989, the Continuation of 1968," Review (Fernand Braudel Center) 15, no. 2 (Spring 1992), 221-42. 